\title{
PENINGKATAN KAPASITAS TENAGA PENDIDIK DAN KEPENDIDIKAN DI SMP NEGERI KEMBES
}

\author{
Donal M. Ratu \\ Universitas Negeri Manado \\ donalratu@unima.ac.id
}

\begin{abstract}
Abstrak
Pengelolaan pendidik dan tenaga kependidikan perlu menjadi perhatian khusus, dikarenakan perannya sebagai fasilitator dan pelayan pendidikan. Pendidik dan tenaga kependidikan perlu diberikan ruang lebih untuk mengupayakan pengembangan profesionalnya. Pembinaan terhadap pendidik dan tenaga kependidikan juga sangat diperlukan guna menyempurnakan proses penyelenggaraan pendidikan serta menjaga kualitas mutu pendidikan anak usia dini. Akan tetapi, tantangan besar bagi pendidik dan tenaga kependidikan di SMP N kembes saat ini berasal dari kualifikasi dan juga berasal dari arus gelombang teknologi dan informasi. Perlu adanya peningkatan mutu pendidikan, upaya yang perlu dilakukan pendidik dan tenaga kependidikan diorientasikan kepada peningkatan kualifikasi dan juga diperlukan adanya pembinaan yang berkelanjutan dari pengawas maupun pemerintah. Harapannya dengan pengelolaan yang baik terhadap pendidik dan tenaga kependidikan dapat memacu motivasi kerja guna tercapainya tujuan pendidikan. Tingkat efektivitas dan efisiensi hasil pendidikan nasional dapat dioptimalkan melalui peningkatan profesionalitas pendidik dan tenaga kependidikan. Profesionalitas dan kualitas dapat terjaga melalui peningkatan kualifikasi, pembinaan, dan pengembangan keprofesionalan serta kinerja yang baik. Untuk menjaga mutu manajemen harus dilakukan perencanaan, pelaksanaan, dan pengembangan secara sungguh-sungguh melalui pembinaan, pelatihan, mentoring kepada seluruh komponen lembaga atau sekolah terutama staf-staf didalam lembaga pendidikan. Kegiatan ini bertujuan untuk membekali pengetahuan tentang peningkatan mutu pendidikan, upaya yang perlu dilakukan pendidik dan tenaga kependidikan diorientasikan kepada peningkatan kualifikasi dan memekali pengetahuan tentang strategi pembelajaran yang tepat untuk diterapkan dalam proses pembelajaran
\end{abstract}

Kata kunci : pendidik, tenaga kependidikan, strategi 


\section{PENDAHULUAN}

\section{A. Analisis Situasi :}

Pendidikan adalah keterampilan dasar yang akan mendukung kemampuan seorang guru dalam menjalankan tugasnya,artinya tinggi rendahnya motivasi seorang guru akan terlihat dari upaya yang dilakukan dalam mengembangkan pendidikannya. Dalam memantau kegiatan belajar siswa,guru hendaknya memahami tentang bagaimana siswa melakukan kegiatan belajar. Serta guru juga dituntut untuk menumbuhkan semangat siswa agar tidak takut untuk bertanya dan menjawab pertanyaan temannya. Karena siswa perlu diajarkan untuk berani mengambil keputusan untuk mengacungkan tangan untuk bertanya ataupun menjawab pertanyaan guru ataupun pertanyaan dari temannya.Guru perlu kreatif dalam menciptakan atmosfer kelas yang kondusif, untuk mendorong siswa agar secara tidak sadar memaksa dirinya menggunakan kemampuan verbalnya untuk bertanya dan menjawab pertanyaan. Karena menurut Surya (2005:8) menjelaskan "Pembelajaran adalah salah satu proses yang dilakukan individu untuk memperoleh suatu perubahan perilaku yang baru secara keseluruhan,sebagai hasil dari pengalaman individu sendiri dalam interaksi dengan lingkungannya". maka keaktifan siswa dalam kegiatan pembelajaran sangat tergantung dari pemanfaatan potensi yang dia miliki oleh siswa itu sendiri.dan keaktifan siswa dalam menjalani proses belajar mengajar merupakan salah satu kunci keberhasilan pencapaian tujuan pembelajaran.

Persoalan pendidikan selaras dengan tuntutan perkembangan dan menjadi issu yang menarik untuk diperbincangkan dan dikaji. Masalah pendidikan dihadapkan pada empat masalah besar, yaitu: masalah mutu, masalah pemerataan, masalah motivasi dan keterbatasan sumber daya dan sumber dana yang dimiliki. Sumber daya dalam hal ini pendidik dan tenaga pendidikan merupakan sentral dari upaya peningkatan mutu pendidikan, karena itu setiap upaya untuk membenahi pendidikan akan dan harus memelihara penataan terhadap guru/pendidik, pemimpinan/tenaga kependidikan yang mampu memanajerial seluruh komponen lembaga/sekolah, terutama pendidik dan tenaga kependidikan. Pendidik dan tenaga kependidikan disinyalir sarat dengan berbagai persoalan, diantaranya persoalan kualifikasi, pembinaan, pengembangan keprofesionalan serta kinerja yang terus perlu diperhatikan secara berkelanjutan untuk terjaganya mutu pendidikan dan tercapainya tujuan pendidikan secara nasional. Kesungguhan pemerintah dan berbagai pihak pemerhati pendidikan dalam memberikan perhatian terhadap dunia pendidikan melalui upaya pemenuhan dan 
perwujudan segenap standar pendidikan tersebut akan menentukan kualitas/mutu pendidikan. Berbagai kegiatan telah diupayakan pemerintah sebagai sarana bagi guru agar mampu merespon

perubahan, tuntutan

perkembangan iptek dan kemajuan masyarakat, termasuk pula di dalamnya perubahan sistem pendidikan dan pembelajaran secara mikro. Tantangan pendidikan Indonesia saat ini bukan hanya terletak pada upaya peningkatan mutu, tetapi juga terletak pada peningkatan kesesuaian pendidikan dengan aneka sektor kehidupan.

Pendidik dan tenaga kependidikan merupakan salah satu kunci utama berhasilnya pergerakan pendidikan dalam rangka pemenuhan standar mutu. Mendidik anak usia sekolah menegah pertama sangat membutuhkan sistem manajemen yang tepat, peningkatan mutu pendidikan harus diawali dari pendidik dan tenaga kependidikan yang professional. Pendidik dan tenaga kependidikan yang berkualitas didukung dengan perencanaan kurikulum dan proses implementasi yang tepat, maka mutu layanan pendidikan anak usia sekolah menegah pertamaakan semakin baik dan mampu melahirkan anak-anak hebat dan tercapainya cita-cita Negara untuk membentuk anak-anak yang memiliki karakter bangsa sejak usia muda.
Perubahan kurikulum pada satuan pendidikan dasar dan menengah di indonesiamembawa banyak perubahan dalam proses pembelajaran. Sebelum dibatalkan (dievaluasi) pada tahun ini kurikulum 2013 sempat diterapkan disemua sekolah, setelah dilakukan evaluasi maka sekolah diberi keleluasaan untuk memilih antara meneruskan kurikulum 2013 atau kembali ke kurikulum KTSP. Kurikulum 2006 (KTSP) berganti dengan kurikulum 2013 yang menekankan digunakannya pendekatan saintifik dalam proses pembelajaran. Perubahan ini mengubah cara mengajar guru dari memberi menjadi fasilitator. Perubahan dalam cara mengajar ini disatu sisi merupakan tantangan bagi guru, tetapi disisi lain juga mengharuskan guru memiliki strategi yang berbeda dalam proses pembelajaran

Keberadaan kurikulum 2013 menjadi satu dorongan untuk meningkatkan kapasitas pengajaran yang dilakukan guru, salah satunya dengan melakukan peningkatan kapasitas guru dalam memilih strategi pembelajaran yang tepat untuk diterapkan dalam proses pembelajaran.

Peran guru dalam sistem pembelajaran merupakan peran vital dan krusial, dimana guru menjadi ujung tombak implementasi proses pembelajaran. Pentingnya peran guru mendorong usaha untuk selalu meningkatkan kualitas guru, dengan harapan guru mampu 
bertransformasi menjadi sosok professional yang mampu mengakomodir dan mengelola pembelajaran dengan baik.

Upaya peningkatan kualitas guru telah dimulai dengan adanya produk hukum tentang pendidikan seeprti UU RI No. 20/2003 tentang Sistem Pendidikan Nasional (Sisdiknas), UU RI No.14/2005 tentang Guru dan Dosen, serta PP RI No.19/2005 tentang Standar Nasional Pendidikan. Berdasarkan produk hukum tersebut dinyatakan bahwa guru adalah pendidik professional yang harus memenuhi persyaratan kualifikasi akademik dan kompetensi. Secara operasional kualifikasi akademik dan kompetensi tersebut diukur atas standar dari Peraturan Menteri Pendidikan Nasional nomor 16 tahun 2007 tentang standar kualifikasi akademik dan kompetensi guru.

Permendiknas Nomor 16 Tahun 2007 menyatakan bahwa terdapat empat standar kompetensi yang ada pada guru, yaitu: Kompetensi Pedagogik, Sosial, Profesional dan Kepribadian. Pada hakikatnya, kompetensi yang dimiliki guru adalah untuk mendapatkan guru yang baik dan profesional yang memiliki kompetensi untuk melaksanakan fungsi dan tujuan pendidikan sesuai tuntutan zaman. Kompetensi tersebut akan teraktualisasi dalam penguasaan pengetahuan, keterampilan maupun sikap profesional dalam menjalankan fungsi sebagai seorang guru. Salah satu standar kompetensi inti guru yaitu mengembangkan keprofesionalan secara berkelanjutan dengan melakukan tindakan reflektif, yang dirumuskan dalam kompetensi guru melakukan penelitian tindakan kelas.

Pada kenyataannya, masih ada guru yang menjalankan fungsinya belum memenuhi standar kompetensi tersebut. Kondisi ini menggambarkan bahwa kemampuan penguasaan guru terhadap materi standar kompetensi professional masih relatif rendah. Adanya permasalahan tersebut mendorong para akademisi perguruan tinggi untuk membantu memfasilitasi upaya peningkatan mutu pembelajaran terutama terkait dengan kemampuan mengembangkan strategi pembelajaran. Langkah tersebut diambil sebagai salah satu bentuk tanggung jawab dan tugas kemasyarakatan sebagaimana diamanatkan dalam tridarma perguruan tinggi. Pengabdian masyarakat dipandang perlu dilakukan sebagai sarana untuk menjembatani kampus dengan masyarakat.

\section{B. Permasalahan Mitra}

Sebagai mitra dalam pelaksanaan kegiatan pengabdian pada masyarakat ini adalah Tenaga Pendidik dan Tenaga Kependidikan di SMPN Kembes. Permasalahan yang teridentifikasi yang menjadi titik tolak kegiatan pengabdian pada masyarakat yang diusulkan ini terfokus pada beberapa masalah yang dihadapi oleh mitra yaitu : 
1. Bagaimana peningkatan mutu pendidikan, upaya yang perlu dilakukan pendidik dan tenaga kependidikan diorientasikan kepada peningkatan kualifikasi

2. Bagaimana strategi pembelajaran yang tepat untuk diterapkan dalam proses pembelajaran

\section{TARGET DAN LUARAN}

\section{A. Target}

Berdasarkan latar belakang pemikiran dan konteks permasalahan yang ada, maka pelaksanaan pelatihan ini bertujuan, terutama untuk menghasilkan peningkatan mutu pendidikan, upaya yang perlu dilakukan pendidik dan tenaga kependidikan diorientasikan kepada peningkatan kualifikasi dan juga memperhatikan profesionalitas dan kualitas pendidik serta tenaga kependidikannya, hal ini dilakukan untuk memberikan jaminan kepada pengguna SMP bahwa pendidikan yang diberikan memiliki pelayanan yang baik

\section{B. Luaran}

Luaran yang diharapkan melalui pelaksanaan kegiatan pengabdian pada masyarakat ini adalah sebagai berikut :

1. Guru-guru dapat mengikuti perkembangan, maksud, dan tujuan kurikulum dan mampu mengimplementasikannya dalam pembelajaran, melalui pengembangan strategi pembelajaran.
2. Guru-guru dapat menyusun, melaksanakan, dan mengembangkan dengan baik pembelajaran di sekolah

3. Meningkatnya kompetensi guru terutama kompetensi pedagogik dan prosefional sesuai Permendiknas Nomor 16 Tahun 2007 tentang kualifikasi akademik dan kompetensi guru

4. Manajerial sekolah yang baik. Kegiatan manajaemen pendidik dan tenaga kependidikan di SMP N Kembes terdiri dari perencanaan pegawai, pengadaan pegawai, pembinaan, promosi dan mutasi, pemberhentian, kompensasi, dan penilaian (Mulyasa, 2009).

\section{METODE PELAKSANAAN}

\section{A. Metode Kegiatan}

Pelaksanaan Iptek pada masyarakat ini adalah workshop dan pelatihan bagi tenaga pendidik yaitu Guru-guru untuk dapat menyusun, melaksanakan, dan mengembangkan dengan baik pembelajaran di sekolah dan bagi tenaga kependidikan yaitu Kegiatan manajaemen pendidik dan tenaga kependidikan di SMP N Kembes terdiri dari perencanaan pegawai, pengadaan pegawai, pembinaan, promosi dan mutasi, pemberhentian, kompensasi, dan penilaian

\section{B. Prosedur Pelaksanaan}

Dalam kegiatan Wokshop akan diberikan Materi:

\section{Peran dan Kompetensi Guru}


Peran guru yang dimaksud adalah berkaitan dengan peran guru dalam proses pembelajaran. Menurut Depdiknas (2008: 8) proses pembelajaran merupakan suatu proses yang mengandung serangkaian perbuatan guru dan siswa atas hubungan timbal balik yang berlangsung dalam situasi edukatif untuk mencapai tujuan tertentu, dimana dalam proses tersebut terkandung multi peran guru. Peran guru tersebut meliputi banyak hal yaitu guru dapat berperan sebagai pengajar, pemimpin kelas, pembimbing, pengatur lingkungan belajar, perencana pembelajaran, supervisor, motivator dan sebagai evaluator. Sedangkan peranan guru berkaitan dengan kompetensi guru meliputi:
a. Guru melakukan diagnosa terhadap perilaku awal siswa.
b. Guru membuat perencanaan pelaksanaan pembelajaran (RPP).
c. Guru melaksanakan proses pembelajaran.

d. Guru sebagai pelaksana administrasi sekolah.

e. Guru sebagai komunikator.

f. Guru mampu mengembangkan keterampilan diri.

g. Guru dapat mengembangkan potensi anak. Louise Moqvist (2003: 23) mengemukakan bahwa "competency has been defined in the light of actual circumstances relating to the individual and work". Sementara itu, Len Holmes (1992) menyebutkan bahwa: "A competence is a description of something which a person who works in a given occupational are should be able to do. It is a description of an action, behaviour or outcome which a person should be able to demonstrate."

Dari kedua pendapat di atas kita dapat menarik benang merah bahwa kompetensi pada dasarnya merupakan gambaran tentang apa yang seharusnya dapat dilakukan (be able to do) seseorang dalam suatu pekerjaan, berupa kegiatan, perilaku dan hasil yang seharusnya juga dapat ditampilkan atau ditunjukkan. Agar dapat melakukan (be able to do) sesuatu dalam pekerjaannya, tentu saja seseorang harus memiliki kemampuan (ability) dalam bentuk pengetahuan (knowledge), sikap (attitude) dan keterampilan (skill) yang sesuai dengan bidang pekerjaannya.

Mengacu pada pengertian kompetensi tersebut, maka dalam hal ini kompetensi guru dapat dimaknai sebagai gambaran tentang apa yang seharusnya dapat dilakukan oleh seorang guru dalam melaksanakan pekerjaannya, baik berupa kegiatan, berperilaku maupun hasil yang dapat ditunjukkan dalam proses pembelajaran.

Berdasarkan Peraturan Menteri Pendidikan Nasional (Permendiknas) Nomor 16 Tahun 2007 dinyatakan bahwa kualifikasi akademik Guru SMA/MA atau sederajat harus berpendidikan diploma empat (D-IV) atau sarjana sesuai dengan 
mata pelajaran yang diajarkan/diampu, dan diperoleh dari program studi yang terakreditasi. Permendiknas itu juga menyatakan bahwa terdapat empat standar kompetensi yang ada pada guru, yaitu: Kompetensi Pedagogik, Sosial, Profesional dan Kepribadian. Penjabaran masingmasing kompetensi lebih jauh dapat dicermati dalam Permendiknas Nomor 16 tahun 2007.

Profesionalisme dapat diartikan sebagai komitmen para anggota suatu profesi untuk meningkatkan kemampuan profesionalnya dan terus menerus mengembangkan strategi-strategi yang digunakannya dalam melakukan pekerjaan sesuai dengan profesinya itu. (Sudarwan Danim, 2002: 23). Guru adalah pendidik profesional dengan tugas utama mendidik, mengajar, membimbing, mengarahkan, melatih, menilai dan mengevaluasi peserta didik pada pendidikan usia dini jalur pendidikan formal, pendidikan dasar dan pendidikan menengah. Kemampuan yang harus dimiliki guru dalam kompetensi profesional menurut Depdiknas (2008: 8) dapat diamati dari aspek-aspek:

a. Menguasai materi, struktur, konsep dan pola fikir keilmuan yang mendukung.

b. Menguasai Standar Kompetensi (SK) dan Kompetensi Dasar (KD) mata pelajaran/bidang pengembangan yang diampu. c. Mengembangkan materi pelajaran yang diampu secara kreatif.

d. Mengembangkan keprofesionalan secara berkelanjutan dengan melakukan tindakan reflektif.

e. Memanfaatkan teknologi informasi dan komunikasi untuk berkomunikasi dan mengembangkan diri.

2. Strategi Pembelajaran

Peningkatan kualitas pembelajaran ditentukan ketika berlangsungnya proses pembelajaran. Di dalam sebuah proses pembelajaran, aktivitas dilakukan tidak hanya berkutat di dalam kelas, tatap muka dengan siswa, tetapi proses pembelajaran sudah dimulai jauh sebelumnya ketika guru merencanakan seperti apa nantinya pembelajaran akan dilakukan. Dalam perencanaan pembelajaran, faktor materi, media, metode, strategi pembelajaran dan evaluasi menjadi bagian penting untuk menghasilkan proses pembelajaran yang baik. Darii beberapa faktor tersebut, strategi pembelajaran memiliki pengaruh yang besar dalam menentukan efektif tidaknya proses pembelajaran. Strategi pembelajaran merupakan langkah-langkah yang digunakan dalam kegiatan belajar yang dilakukan untuk mencapai tujuan dengan cara yang efektif dan efisien (Suyanto \& Djihad, 2012:92). Menurut Suyanto \& Djihad (2012) ada 4 aspek di dalam strategi pembelajaran, yaitu: 
1. Mengidentifikasi dan menetapkan spesifikasi sertakualifikasi perubahan tingkah laku yang diharapkan

2. Memilih cara pendekatan belajar yang tepat untuk mencapai standar kompetensi, dengan memperhatikan karakteristik siswa sebagai subyek belajar

3. Memilih dan menetapkan sejumlah prosedur, metode, dan teknik kegiatan pembelajaran yang relevan dengan kebutuhan pengalaman belajar yang mesti diempuh siswa

4. Menetapkan norma dan kriteria keberhasilan, agar dapat menjadi pedoman dalam kegiatan pembelajaran

\section{HASIL DAN PEMBAHASAN}

Kegiatan pembelajaran Bahasa Jepang praktis pada Tenaga Pendidik dan Tenaga Kependidikan di SMPN Kembes, dilaksanakan pada tanggal 7 Mei 2019 di pembelajaran SMPN Kembes. Metode yang digunakan dalam kegiatan pembelajaran Metode pendekatan yang digunakan dalam kegiatan ini adalah pendekatan praktis pragmatis-tematis dan pragmatis teoritis.

1. Metode pendekatan pragmatis teoritis

Metode ini dimaksudkan agar materi strategi pembelajaran dapat disampaikan secara optimal. Materi ini disampaikan dengan metode ceramah, tanya jawab, demontrasi, dan diskusi di kelas. a. Ceramah dan Tanya Jawab. Ceramah dilakukan sebagai salah satu bentuk pengenalan tentang materi. kegiatan yang dilakukan pada umumnya, memberikan pengetahuan tentang segala sesuatu yang nantinya bisa peserta dapatkan. Kegiatan ini dipadu dengan tanya jawab sebagai salah satu alternative mendekatkan diri antara pengabdi dengan peserta, sekaligus untuk mengetahui seberapa jauh pemahaman peserta.

b. Demonstrasi

$$
\text { Memperlihatkan contoh }
$$
beberapa strategi pembelajaran yang pernah dan sering dilakukan dan langkah-langkah manajerial dalam suatu lembaga pendidikan. Demonstrasi dilaksanakan sebagai sarana untuk mengugah motivasi peserta bahwa pelatihan ini tidak hanya utopia belaka, hanya sekedar pelatihan tanpa ada produk, tetapi ada hasil nyatanya. Selain itu demonstrasi juga dilakukan untuk memperlihatkan beberapa tampilan strategi pembelajaran dengan media dalam konteks yang sebenarnya. Dalam pelatihan ini, demontrasi penting untuk memperlihatkan kepada peserta tentang berbagai strategi pembelajaran.

c. Pelatihan dan Praktek

Kegiatan ini dilaksanakan dengan cara memberikan pelatihan plus praktek secara langsung tentang Strategi Pembelajaran dan langkah-langkah 
manajerial dalam suatu lembaga pendidikan. Proses dimulai dengan memberikan materi tentang strategi pembelajaran, media yang digunakan. Strategi pembelajaran yang dipilih nantinya berdasarkan observasidan permasalahan yang ada di sekolah. Hal ini menyesuaikan dengan materi pelajaran, karakteristik siswa, dan dukungan sarana prasarana. Setelahnya peserta diberikan kesempatan untuk membuat strategi pembelajaran yang nantinya akan dipraktekkan di kelas sesuai jadwal.

Untuk kegiatan pelatihan strategi pembelajaran, pertemuan dimulai dengan penjelasan materi dan paparan tentang segala macam bentuk strategi pembelajaran. Dalam kesempatan ini juga diperkenalkan dengan beragam strategi yang didalamnya mencakup pilihan metode dan media yang digunakan dalam proses pembelajaran. Pada kegiatan ini terbuka diskusi antara guru dengan tim pengabdi untuk sharing terkait proses pembeajaran dalam kelas yang sesunguhnya. Selain pelatihan juga di demonstrasikan salah satu strategi pembelajaran dengan mengoptimalkan peran media. Strategi dengan mengoptimalkan peran media dipilih media yang mampu memaksimalkan peran aktif peserta didik. Dalam hal ini yang didemonstrasikan adalah wayang sosiologi, dimana nantinya peserta didik diminta untuk menjelaskan materi pembelajaran dengan bantuan wayang. Tidak hanya mendemonstrasikan, guru juga diajak untuk bersama-sama mencoba membuat wayang dengan tutorial dari tim pengabdi.

2. Metode pendekatan praktis pragmatis Metode ini digunakan dengan maksud agar dalam waktu yang terbatas ini, guru dapat menguasai materi. Para guru diajak melakukan praktik membuat rancangan dan mengimplementasikan variasi strategi pembelajaran pada pelajaran . Tenaga kependidikan di ANAK USIA SEKOLAH MENEGAH PERTAMA adalah pengelola satuan pendidikan anak usia dini yang bertugas melaksanakan tugas administrasi seperti pustakawan, teknisi sumber belajar, laboran, pengawas, penilik, dan peneliti yang menjalankan fungsi mendukung pelaksanaan pendidikan (Danim, 2016: 18). Tenaga kependidikan anak usia dini merupakan tenaga yang bertugas melaksanakan administrasi, pengelolaan, pengembangan, pengawasan dan pelayanan teknis untuk menunjang proses pendidikan pada satuan dan atau program ANAK USIA SEKOLAH MENEGAH PERTAMA. Tenaga kependidikan terdiri atas pengawas, Pemilik, Kepala ANAK USIA SEKOLAH MENEGAH PERTAMA, tenaga administrasi dan tenaga penunjang lainya (Permendikbud No.137 tahun 
2014 tentang Standar Nasional Pendidikan Sekolah Menengah Pertama

\section{KESIMPULAN DAN SARAN}

\section{A. Kesimpulan}

1. Pengembangan strategi dan media pembelajaran yang dilakukan oleh guru paling tidak kemudian harus melihat beberapa hal, yang paling tidak dimiliki dan dipahami oleh guru:

[? Strategi pembelajaran menyesuaikan dengan materi yang diajarkan

(3) Strategi pembelajaran menyesuaikan denagn karakteristik siswa

?. Pengajaran yang bermakna lebih mendorong partisipasi aktif siswa

0. Media pembelajaran tidak harus dibuat oleh guru tetapi juga bisa melibatkan siswa

?. Melihat tujuan pembelajaran

(3) Melihat kemampuan guru dalam menggunakan media

? Variasi dalam penggunaan media

?] Sinkronisasi dengan materi pembelajaran yang diajarkan

Pada intinya pelaksanaan pelatihan pengembangan strategi pembelajaran berjalan dengan baik dan lancar, follow up dari kegiatan ini nantinya diharapkan peserta pelatihan untuk terus mencoba mengembangkan kreativitasnya dalam mengembangan media pembelajaran dan mencoba mengunakan strategi pembelajaran yang tepat untuk peserta didik. Hanya saja yang masih menjadi kendala menurut sebagian besar peserta, adalah ketiadaaan waktu mereka untuk mengembangkan media karena kebutuhan jam pembelajaran yang besar. Banyak guru yang tidak punya semangat untuk membuat media. Sekolah tidak memfasilitasi pembuatan media pembelajaran. Kurangnya kretivitas guru dalam pelaksanaan pembelajaran. Hal inilah yang menurut peserta terkandang menurunkan animo mereka untuk belajar lebih lanjut.

2. Pengelolaan pendidik dan tenaga kependidikan perlu menjadi perhatian khusus, dikarenakan perannya sebagai fasilitator dan pelayan pendidikan. Pendidik dan tenaga kependidikan perlu diberikan ruang lebih untuk mengupayakan pengembangan profesionalnya. Pembinaan terhadap pendidik dan tenaga kependidikan juga sangat diperlukan guna menyempurnakan proses penyelenggaraan pendidikan serta menjaga kualitas mutu pendidikan anak usia dini. Akan tetapi, tantangan besar bagi pendidik dan tenaga kependidikan di SMP N kembes saat ini berasal dari kualifikasi dan juga berasal dari arus gelombang teknologi dan informasi.

3. Perlu adanya peningkatan mutu pendidikan, upaya yang perlu 
dilakukan pendidik dan tenaga kependidikan diorientasikan kepada peningkatan kualifikasi dan juga diperlukan adanya pembinaan yang berkelanjutan dari pengawas maupun pemerintah. Harapannya dengan pengelolaan yang baik terhadap pendidik dan tenaga kependidikan dapat memacu motivasi kerja guna tercapainya tujuan pendidikan

4. Tingkat efektivitas dan efisiensi hasil pendidikan nasional dapat dioptimalkan melalui peningkatan profesionalitas pendidik dan tenaga kependidikan. Profesionalitas dan kualitas dapat terjaga melalui peningkatan kualifikasi, pembinaan, dan pengembangan keprofesionalan serta kinerja yang baik. Untuk menjaga mutu manajemen harus dilakukan perencanaan, pelaksanaan, dan pengembangan secara sungguhsungguh melalui pembinaan, pelatihan, mentoring kepada seluruh komponen lembaga atau sekolah terutama stafstaf didalam lembaga pendidikan

\section{B. Saran}

1. Perlunya penyelenggaraan kegiatankegiatan pengembangan untuk pendidik dan tenaga kependidikan adalah salah satu upaya untuk menjaga kualitas dan mutu pendidikan di Indonesia. Arus teknologi dan informasi saat ini bukan hanya menggerus anak muda, namun sudah menjadi tren bagi semua kalangan masyarakat. Pendidik dan tenaga kependidikan perlu melakukan pemilihan informasi sebelum disampaikan kepada siswa.

2. Kegiatan pengabdian pada masyarakat dalam bentuk workshop dan pelatihan Manajerial pada Tenaga Pendidik dan Tenaga Kependidikan di SMPN Kembes telah dilaksanakan dengan baik dan telah mencapai tujuan yang dilaksanakan tinggal perlu ditindaklanjuti dengan bentuk pengabdian dengan judul berbeda.

\section{KEPUSTAKAAN}

Abdul Gafur, (1998), Pemanfaatan Teknologi dan Media Pendidikan untuk Meningkatkan Kemampuan Profesional Tenaga Kependidikan, Yogyakarta: IKIP

Budiningsih, C. Asri, (1995), Strategi Menggunakan Media Pengajaran bagi Pendidikan Dasar, Yogyakarta: LPM IKIP Yogyakarta.

Fleming, Malcom dan W Howard Levie, (1988), Instructional Masage Design, New Jersey: Educational Technology Publications.

Gagne, R.M, (1974), Essentials of Learning for Instruction, Hindsdal: The Dryden Press.

Kinder, J.S, (1973), Using Instructional Media, New York: D. Van Nostradn Company. Nursid Sumaatmadja. 
(1996). Metodologi Pengajaran Geografi. Jakarta: Bumi Aksara Reigeluth, C.M. (2010). Technology and the new paradigm of education. Contemporary Educational Technology, Bloomingtoon: Indianauniversity.

Slavin, Robert. (2009) Cooperative Learning Teori, Riset dan Praktik (Edisi Terjemahan). Bandung: Nusa Media Soedjono, Soeprapto, (2005), Pot-Pourri Fotografi, Jakarta: Penerbit Universitas Trisakti. Sudarwan Danim, (2002). Inovasi pendidikan dalam upaya peningkatan profesionalisme tenaga kependidikan. Jakarta: Pustaka Setia Suyanto \& Djihad. (2012). Calon Guru dan Guru Profesional. Yogyakarta: Multi Pressindo
Wenger, Win, (2004), Beyond Teaching \& Learning, Bandung: Nuansa.

Wina Sanjaya, (2006). Strategi Pembelajaran Berorientasi Standar Proses Pendidikan. Jakarta: Kencana Prenada Media Group

UU nomor 20 tahun 2003 Permendiknas Nomor 16 tahun 2007 tentang Standar Kualifikasi Akademik dan Kompetensi Guru. Denim.2016. Inovasi Pendidikan Dalam Upaya Peningkatan Profesionalisme Tenaga Kependidikan. Bandung: CV Pustaka Setia.

Gomes,C. F. 2003. Manajemen Sumber Daya Manusia. Yogyakarta: CV ANDI Offset Heryatidan Muhsin, 2014. Manajemen Sumber Daya Pendidikan. Bandung: CV Pustaka Setia 